\title{
Evaluation of healthy lifestyle behaviors and related factors in medical students
}

\section{Tıp fakülltesi öğrencillerinde sağlık\|l yaşam biçiımi davranışlarının ve ilişkili faktörlerin değerlendirilmesi}

\author{
Ali Dörtkol, Levent Özdemir
}

Bursa Uludağ University Faculty of Medicine, Public Health Department, Bursa, Turkey

Corresponding author: Ali Dörtkol, MD, Bursa Uludağ University Faculty of Medicine, Public Health Department, Bursa, Turkey

E-mail: dralidortkol@gmail.com

Received/Accepted: December 07, 2020 / March 31, 2021

Conflict of interest: There is not a conflict of interest.

\section{SUMMARY}

Objective: A healthy lifestyle can be defined as the adoption and implementation of behaviors that will reduce the risk of a serious illness or premature death, as well as protect and improve health levels. The aim of this study was to determine healthy lifestyle behaviors of students in a medical faculty and to investigate the relationships between healthy lifestyle behaviors and various factors.

Method: This descriptive cross-sectional study was conducted at Bursa Uludağ University Faculty of Medicine between October 2019 and March 2020. A total of 357 students attending the first and sixth grade of medical faculty were included in the study. The data were collected by a questionnaire included questions about the sociodemographic characteristics of the participants and Healthy Lifestyle Behaviors Scale II (HLBS-II).

Results: Of the respondents, $54.3 \%(n=194)$ were women and $52.7 \%$ $(n=188)$ were sixth-year graduates. Most of them were living apart from family (in a private house or dormitory) $(\mathrm{n}=258,72.3 \%)$ and stated their health status as very good/good $(n=286,80.1 \%)$. Students, who were living with their families $(\mathrm{p}=0.039)$, who had very good/good level of health status perception $(\mathrm{p}<0.001)$, whose fathers' educational level was high school or above $(p=0.004)$, who were non-smokers $(p=0.003)$, and who were not drinking alcohol $(\mathrm{p}=0.001)$ had significantly higher HLBS-II total scores. Furthermore, HLBS-II total score $(\mathrm{p}=0.003)$, physical activity $(\mathrm{p}<0.001)$, spiritual growth $(\mathrm{p}<0.001)$, and interpersonal relationships $(\mathrm{p}=0.039)$ subscale scores of first-year students were significantly higher than sixthyear students.

Conclusions: It was observed that the healthy lifestyle behaviors of medical students did not develop in a positive way despite the education they received. Examining of students' health habits at regular intervals and developing multisectoral on-campus health programs should be considered as an opportunity to improve the health of both students and the community. Keywords: Health promotion, healthy lifestyle, medical education, medical students.
Ali Dörtkol

Levent Özdemir

ORCID IDs of the authors:

A.D. 0000-0002-5307-0008

L.Ö. 0000-0002-4330-8334 
Amaç: Sağlıklı bir yaşam tarzı, ciddi bir hastalık veya erken ölüm riskini azaltmanın yanı sıra sağlık düzeyini koruyan ve iyileştiren davranışların benimsenmesi ve uygulanması olarak tanımlanabilir. Bu çalışmanın amacı, tıp fakültesi öğrencilerinin sağlıklı yaşam biçimi davranışlarını değerlendirmek ve sağlıklı yaşam biçimi davranışları ile çeşitli faktörler arasındaki ilișkileri araștırmaktır.

Yöntem: Tanımlayıcı kesitsel tipteki bu çalışma Ekim 2019- Mart 2020 tarihleri arasında Bursa Uludağ Üniversitesi Tıp Fakültesi'nde yürütülmüş̧ür. Tıp fakültesinin birinci ve altıncı sınıfına devam eden toplam 357 öğrenci çalışmaya dahil edilmiştir. Veriler; katılımcıların sosyodemografik özelliklerine ilişkin sorular ve Sağlıklı Yaşam Biçimi Davranışları Ölçeği II'den (SYBD-II) oluşan bir anket ile toplanmıştır.

Bulgular: Katılımcıların \%54,3'ü (n=194) kadın, \%52,7'si (n=188) altıncı sınıf öğrencisidir. Katılımcıların çoğu ailesinden ayrı (özel bir evde veya yurtta) yaşamaktadır $(\mathrm{n}=258, \% 72,3)$ ve sağlık durumlarını çok iyi/iyi $(\mathrm{n}=286, \% 80,1)$ olarak belirtmiştir. Ailesiyle birlikte yaşayan ( $\mathrm{p}=0,039)$, çok iyi/iyi sağlık durumu algısına sahip olan ( $\mathrm{p}<0,001)$, babasının eğitim düzeyi lise veya üstü olan $(\mathrm{p}=0,004)$, sigara içmeyen $(\mathrm{p}=0,003)$ ve alkol kullanmayan $(\mathrm{p}=0,001)$ öğrencilerin SYBD-II toplam skorları anlamlı olarak daha yüksektir. Ayrıca, birinci sınıf öğrencilerinin SYBD-II toplam puanı $(\mathrm{p}=$ $0,003)$, fiziksel aktivite $(p<0,001)$, manevi gelişim $(p<0,001)$ ve kişilerarası iliş̧iler $(p=0,039)$ alt ölçek puanları altınc1 sinıf öğrencilerinden anlamlı olarak daha yüksektir.

Sonuç: Çalışmamızda tıp öğrencilerinin aldıkları eğitime rağmen sağlıklı yaşam biçimi davranışlarının olumlu yönde gelişmediği görülmüştür. Öğrencilerin sağlık alışkanlıklarının düzenli aralıklarla incelenmesi ve çok sektörlü kampüs içi sağlık programlarının geliştirilmesi hem öğrencilerin hem de toplumun sağlığını iyileştirmek için bir firsat olarak düşünülmelidir.

Anahtar sözcükler: Sağlığı geliştirme, sağlıklı yaşam biçimi, tıp eğitimi, tıp fakültesi öğrencileri.

\section{INTRODUCTION}

A healthy lifestyle can be defined as the adoption and implementation of behaviors that will reduce the risk of a serious illness or premature death, as well as protect and improve health levels ${ }^{1,2}$. Many non-communicable diseases such as cardiovascular diseases, cancers, chronic respiratory diseases, diabetes, which are the main causes of worldwide mortality and morbidity, are closely related to unhealthy lifestyle habits such as poor nutrition, physical inactivity, smoking and heavy alcohol use 3,4 .

Health-related behaviors in youth affect disease risks in later life periods. It is projected that the conditions or behavior that started during the youth period are linked with approximately two-thirds of premature deaths and one-third of the total burden of disease in adulthood ${ }^{5}$.

Healthy lifestyle habits of medical students are important in terms of both being in the young group and being future physicians. A majority of people view their physicians as the main source of information concerning healthy lifestyle ${ }^{6}$. Physicians can reduce years of life lost (YLL) and restrain health expenditures through counseling to people who engage in risky behaviors that can negatively affect their health ${ }^{7}$. However, one of the most important determinants of consultancy on health protection and promotion is whether the physicians practice healthy lifestyle behaviors. In many studies on health protection and promotion, it has been determined that physicians who have positive health habits in many areas such as physical activity, nutrition, alcohol use, smoking provide more consultancy to their patients ${ }^{6,8}$.

Medical students face many challenges brought on by university life during their education. In this period of rapid physical and psychosocial changes, students meet a new environment where academic workload and stress increase, which can contribute to unhealthy lifestyles, and usually move away from the family environment to a process where they gain more autonomy over their lives. Workrelated stress and poor time management come to the forefront as the biggest obstacles to the healthy lifestyle preferences of medical students ${ }^{9}$.

In this study, it was aimed to determine the effect of medical education on healthy lifestyle behaviors by comparing healthy lifestyle behaviors of first and sixth grade students of medical faculty and to examine the relationships between healthy lifestyle behaviors and related factors.

\section{MATERIAL AND METHODS}

\section{Study Design and Participants}

This descriptive cross-sectional study was conducted between October 2019 and March 2020 at Bursa Uludağ University Faculty of Medicine in Bursa, Turkey. The study population consisted of the first and last classes from the medical faculty in the 2019-20 academic year with a total number of 709. Medical students who were non-native Turkish speakers were excluded from the study ( 83 people). Of the 394 students who were reached during the study period, 357 agreed to participate in the study (response rate 90.6\%). 


\section{Data Collection}

The data of the study were collected by an anonymous self-completed questionnaire consisting of two sections and 66 items. The first section of the questionnaire contained questions about the sociodemographic characteristics of the participants (e.g., gender, age, class, education level of parents, history of chronic disease, smoking, alcohol use). In the second part of the questionnaire, Healthy Lifestyle Behaviors Scale II (HLBS-II) was used to investigate the students' health behaviors ${ }^{10}$.

The first version of HLBS was developed by Walker et al. in 1987 and revised in 1996 as HLBSII $^{10,11}$. The Turkish validity and reliability study of the HLBS-II was carried out in 2008 by Bahar et al. ${ }^{12}$. HLBS-II is a 4-point likert type scale (never $=1$, sometimes $=2$, frequently $=3$ and regularly=4) composed of 52 questions and six subscales. The subscales are physical activity, nutrition, spiritual growth, interpersonal relationships, health responsibility and stress management. The total scores of the respondents vary from 52 to 208 , and higher scores indicate good practice of healthy behaviors.

\section{Ethical approval}

The study was approved by the Clinical Trials Ethics Committee of Bursa Uludağ University Faculty of Medicine (Approval date/number: 04.09.2019 / 2019-14/17). All the students were informed about the aim of the study. Participation in the study was voluntary and verbal consent was obtained from those who agreed to participate.

\section{Statistical analysis}

The data was analyzed with SPSS version 23.0 (IBM Corp., Armonk, NY). Sociodemographic characteristics of the students were described with frequencies and percentages. Total HLBS-II and subscales scores of the respondents were presented with mean and standard deviation values. The differences in total HLBS-II and subscale scores between the two groups were compared with the Student-t test or Mann-Whitney U test while for comparison of three or more groups ANOVA or Kruskal-Wallis test was used.

Categorical variables were analyzed with ChiSquare test. When comparing three or more groups, Tukey or Bonferroni test was used for multiple comparisons. Shapiro-Wilk test was performed to explore whether variables have a normal distribution. The statistical significance level was determined as $\mathrm{p}<0.05$.

\section{RESULTS}

\section{Sociodemographic characteristics of participants}

Sociodemographic characteristics of the students are presented in Table 1. The mean age of the participants was $21.6 \pm 3.1$ and $54.3 \%(\mathrm{n}=194)$ of them were women. Of the students, $52.7 \%(n=188)$ were sixth-year students while $47.3 \% \quad(n=169)$ were first-year students. Most of the students $(\mathrm{n}=258,72.3 \%)$ were living apart from their family (in a private house or dormitory). The percentage of students who evaluated their own health status as good or very good was $80.1 \%(n=286)$. The majority of parents were high school or above graduates (62.5\% in mothers, $82.1 \%$ in fathers). Of the students, 9.2\% $(n=33)$ had at least one chronic disease and $12.3 \%(n=44)$ of them were smokers and $20.7 \%(\mathrm{n}=74)$ were using alcohol.

\section{Associations between individual characteristics and HLBS-II}

The HLBS-II total and subscale scores of the participants were given in Table 2. The average HLBS-II score of the students was $125.7 \pm 17.1$. When the scores of the subscales were examined, the spiritual growth subscale had the highest score $(25.9 \pm 4.3)$ whereas the physical activity subscale had the lowest score $(16.4 \pm 4.9)$.

The distribution of the HLBS-II and subscale scores according to sociodemographic characteristics of the students were given in Table 3 . When the total and subscale scores of HLBS-II were compared based on gender, it was found that physical activity scores were significantly higher in males than females $(\mathrm{p}<0.001)$.

The results showed that the place of residence was significantly associated with total HLBS-II $(\mathrm{p}=0.015)$ and nutrition score $(\mathrm{p}=0.015)$. The students who living with their families had significantly higher total HLBS-II $(\mathrm{p}=0.039)$ and nutrition subscale scores $(\mathrm{p}=0.010)$ compared to the students who living in a private house. In addition to this, total HLBS-II scores $(\mathrm{p}=0.030)$ of the students who living in a dormitory were significantly higher than those living in a private house. 
Table 1: Sociodemographic Characteristics of the Participants

\begin{tabular}{|c|c|c|}
\hline & $\mathbf{n}$ & $\%$ \\
\hline \multicolumn{3}{|l|}{ Gender } \\
\hline Female & 194 & 54.3 \\
\hline Male & 163 & 45.7 \\
\hline \multicolumn{3}{|l|}{ Grade } \\
\hline $1^{\text {st }}$ & 169 & 47.3 \\
\hline $6^{\text {th }}$ & 188 & 52.7 \\
\hline \multicolumn{3}{|l|}{ Place of residence } \\
\hline Family house & 99 & 27.7 \\
\hline Private house & 126 & 35.3 \\
\hline Dormitory & 132 & 37.0 \\
\hline \multicolumn{3}{|c|}{ Self-perception of health status } \\
\hline Very good/ Good & 286 & 80.1 \\
\hline Fair/ Poor & 71 & 19.9 \\
\hline \multicolumn{3}{|c|}{ Self-perception of economic status } \\
\hline Very good/ Good & 198 & 55.5 \\
\hline Fair/ Poor & 159 & 44.5 \\
\hline \multicolumn{3}{|l|}{ Education level of mother } \\
\hline Primary school or below & 134 & 37.5 \\
\hline High school or above & 223 & 62.5 \\
\hline \multicolumn{3}{|l|}{ Education level of father } \\
\hline Primary school or below & 64 & 17.9 \\
\hline High school or above & 293 & 82.1 \\
\hline \multicolumn{3}{|c|}{ Presence of a chronic disease } \\
\hline Yes & 33 & 9.2 \\
\hline No & 324 & 90.8 \\
\hline \multicolumn{3}{|l|}{ Smoking } \\
\hline Yes & 44 & 12.3 \\
\hline No & 313 & 87.7 \\
\hline \multicolumn{3}{|l|}{ Alcohol use } \\
\hline Yes & 74 & 20.7 \\
\hline No & 283 & 79.3 \\
\hline
\end{tabular}


When the total HLBS-II and subscale scores were compared according to students' health perception, there were statistically significant differences in all titles except for health responsibility. The students who had very good or good level of health status perception had significantly higher scores than the students who had moderate/bad level of health status perception in terms of total HLBS-II $(\mathrm{p}<0.001)$, physical activity $(\mathrm{p}=0.001)$, nutrition $(\mathrm{p}=0.012), \quad$ spiritual growth $\quad(\mathrm{p}<0.001)$, interpersonal relationships $(\mathrm{p}=0.010)$ and stress management $(\mathrm{p}<0.001)$ subscales. It was also observed that interpersonal relationships scores were significantly higher for the students who had at least one chronic disease $(\mathrm{p}=0.038)$. Nutritional score was found significantly higher for the students who stated their own economic status as good or very good $(\mathrm{p}=0.021)$.

With regard to parents' education level, it was found that the total HLBS-II ( $\mathrm{p}=0.004)$, nutrition $(\mathrm{p}=0.009)$ and physical activity $(\mathrm{p}=0.010)$ scores of the students whose father's level of education was high school or above, were significantly higher than the students whose father's level of education was primary school or below. However, only the nutrition $(\mathrm{p}=0.031)$ score was found to be significantly higher in students whose mother's education level was high school or above.
It was also found significant differences in total HLBS-II and the majority of the subscale scores according to the students' smoking status and alcohol use. The total HLBS-II ( $\mathrm{p}=0.003)$, nutrition $(\mathrm{p}=0.001), \quad$ spiritual growth $\quad(\mathrm{p}<0.001)$, interpersonal relationships $(\mathrm{p}=0.009)$ and stress management $(\mathrm{p}=0.038)$ scores were significantly higher for non-smoking students. Similarly, total HLBS-II ( $\mathrm{p}=0.001)$, nutrition $(\mathrm{p}=0.040)$, spiritual growth $(\mathrm{p}<0.001)$ and stress management $(p=0.006)$ scores were significantly higher for those not drinking alcohol.

Comparison of the first-year and the sixth-year medical students according to HLBS-II total and subscale scores were given in Table 4 . The total HLBS-II ( $\mathrm{p}=0.003)$, physical activity $(\mathrm{p}<0.001)$, spiritual growth $(\mathrm{p}<0.001)$ and interpersonal relationship $(\mathrm{p}=0.039)$ subscale scores of the firstyear students were found to be significantly higher compared to the sixth-year students. Furthermore, $20.2 \%$ of the sixth-grade students were smoking and $25.5 \%$ were drinking alcohol while these percentages were $3.6 \%$ and $15.4 \%$ for the firstgrade students respectively and the differences between the groups were significant $(p<0.001$, $\mathrm{p}=0.018$ respectively).

Table 2: HLBS-II Total and Subscale Scores of the Students

\begin{tabular}{|l|c|c|}
\hline & Mean \pm SD & Min-Max \\
\hline HLBS-II & $125.7 \pm 17.1$ & $73-186$ \\
\hline Subscales & $19.0 \pm 3.7$ & $10-34$ \\
\hline Health Responsibility & $16.4 \pm 4.9$ & $8-32$ \\
\hline Physical Activity & $19.5 \pm 3.8$ & $10-34$ \\
\hline Nutrition & $25.9 \pm 4.3$ & $13-36$ \\
\hline Spiritual Growth & $25.4 \pm 3.9$ & $14-36$ \\
\hline Interpersonal Relationships & $19.1 \pm 3.4$ & \\
\hline Stress Management & & \\
\hline
\end{tabular}


Table 3: Distribution of Participants' HLBS-II Total and Subscale Scores According to Sociodemographic Characteristics

\begin{tabular}{|c|c|c|c|c|c|c|c|}
\hline &  &  &  &  &  &  &  \\
\hline \multicolumn{8}{|l|}{ Gender } \\
\hline Female & $19.2 \pm 3.4$ & $15.5 \pm 4.5$ & $19.5 \pm 3.6$ & $25.7 \pm 4.1$ & $25.7 \pm 4.0$ & $19.0 \pm 3.4$ & $124.7 \pm 15.8$ \\
\hline Male & $18.8 \pm 4.0$ & $17.6 \pm 5.0$ & $19.6 \pm 4.1$ & $26.2 \pm 4.4$ & $25.1 \pm 3.8$ & $19.2 \pm 3.4$ & $126.9 \pm 18.4$ \\
\hline $\mathrm{P}$ value & 0.149 & 0.0001 & 0.629 & 0.296 & 0.081 & 0.856 & 0.227 \\
\hline \multicolumn{8}{|c|}{ Place of residence } \\
\hline $\begin{array}{l}\text { Family } \\
\text { house }\end{array}$ & $19.2 \pm 4.3$ & $16.8 \pm 5.5$ & $20.4 \pm 4.1$ & $26.1 \pm 4.1$ & $25.2 \pm 3.6$ & $19.6 \pm 3.5$ & $127.8 \pm 18.2$ \\
\hline $\begin{array}{l}\text { Private } \\
\text { house }\end{array}$ & $18.6 \pm 3.4$ & $15.6 \pm 4.5$ & $18.9 \pm 3.9$ & $25.3 \pm 4.4$ & $25.0 \pm 4.3$ & $18.6 \pm 3.3$ & $122.2 \pm 17.2$ \\
\hline Dormitory & $19.3 \pm 3.5$ & $17.0 \pm 4.7$ & $19.6 \pm 3.4$ & $26.5 \pm 4.2$ & $25.9 \pm 3.6$ & $19.1 \pm 3.3$ & $127.6 \pm 15.6$ \\
\hline$P$ value & 0.256 & 0.059 & 0.015 & 0.056 & 0.173 & 0.118 & 0.015 \\
\hline \multicolumn{8}{|c|}{ Presence of a chronic disease } \\
\hline Yes & $19.8 \pm 3.3$ & $14.9 \pm 3.8$ & $20.0 \pm 3.5$ & $25.5 \pm 4.2$ & $26.8 \pm 3.4$ & $18.6 \pm 3.7$ & $125.9 \pm 15.3$ \\
\hline No & $18.9 \pm 3.8$ & $16.6 \pm 5.0$ & $19.5 \pm 3.9$ & $26.0 \pm 4.3$ & $25.3 \pm 3.9$ & $19.1 \pm 3.3$ & $125.7 \pm 17.2$ \\
\hline$P$ value & 0.134 & 0.057 & 0.403 & 0.520 & 0.038 & 0.291 & 0.950 \\
\hline \multicolumn{8}{|c|}{ Self-perception of health status } \\
\hline $\begin{array}{l}\text { Very good/ } \\
\text { Good }\end{array}$ & $19.1 \pm 3.6$ & $16.8 \pm 4.9$ & $19.8 \pm 3.7$ & $26.4 \pm 4.0$ & $25.7 \pm 3.8$ & $19.4 \pm 3.3$ & $127.5 \pm 16.4$ \\
\hline Fair/Poor & $18.6 \pm 4.0$ & $14.8 \pm 4.6$ & $18.7 \pm 4.2$ & $23.9 \pm 4.6$ & $24.3 \pm 4.0$ & $17.9 \pm 3.4$ & $118.6 \pm 18.0$ \\
\hline
\end{tabular}




\begin{tabular}{|c|c|c|c|c|c|c|c|}
\hline &  &  & &  &  &  &  \\
\hline$P$ value & 0.285 & 0.001 & 0.012 & 0.0001 & 0.010 & 0.0001 & 0.0001 \\
\hline \multicolumn{8}{|c|}{ Self-perception of economic status } \\
\hline $\begin{array}{l}\text { Very good/ } \\
\text { Good }\end{array}$ & $19.1 \pm 3.9$ & $16.8 \pm 4.9$ & $20.0 \pm 4.0$ & $26.2 \pm 4.2$ & $25.5 \pm 4.0$ & $19.2 \pm 3.4$ & $127.2 \pm 17.4$ \\
\hline Fair/Poor & $18.9 \pm 3.5$ & $16.0 \pm 4.9$ & $19.0 \pm 3.6$ & $25.6 \pm 4.3$ & $25.3 \pm 3.8$ & $18.9 \pm 3.3$ & $123.9 \pm 16.5$ \\
\hline$P$ value & 0.789 & 0.093 & 0.021 & 0.133 & 0.522 & 0.349 & 0.073 \\
\hline \multicolumn{8}{|l|}{ Smoking } \\
\hline Yes & $18.2 \pm 4.3$ & $15.6 \pm 4.7$ & $17.6 \pm 3.4$ & $23.7 \pm 4.8$ & $23.9 \pm 4.1$ & $18.2 \pm 3.4$ & $117.5 \pm 18.6$ \\
\hline No & $19.1 \pm 3.6$ & $16.5 \pm 4.9$ & $19.8 \pm 3.8$ & $26.3 \pm 4.1$ & $25.6 \pm 3.8$ & $19.2 \pm 3.4$ & $126.9 \pm 16.5$ \\
\hline$P$ value & 0.114 & 0.257 & 0.001 & 0.0001 & 0.009 & 0.038 & 0.003 \\
\hline \multicolumn{8}{|l|}{ Alcohol use } \\
\hline Yes & $18.3 \pm 3.7$ & $16.0 \pm 4.8$ & $18.6 \pm 3.9$ & $23.8 \pm 4.5$ & $24.7 \pm 4.0$ & $18.1 \pm 3.0$ & $120.0 \pm 17.5$ \\
\hline No & $19.2 \pm 3.7$ & $16.6 \pm 4.9$ & $19.8 \pm 3.8$ & $26.5 \pm 4.0$ & $25.6 \pm 3.9$ & $19.3 \pm 3.4$ & $127.2 \pm 16.7$ \\
\hline$P$ value & 0.076 & 0.422 & 0.040 & 0.0001 & 0.139 & 0.006 & 0.001 \\
\hline \multicolumn{8}{|c|}{ Education level of mother } \\
\hline $\begin{array}{l}\text { Primary } \\
\text { school or } \\
\text { below }\end{array}$ & $18.8 \pm 3.4$ & $16.3 \pm 4.8$ & $19.0 \pm 3.9$ & $26.0 \pm 4.0$ & $25.2 \pm 3.8$ & $19.0 \pm 3.3$ & $124.6 \pm 16.0$ \\
\hline $\begin{array}{l}\text { High } \\
\text { school or } \\
\text { above }\end{array}$ & $19.1 \pm 3.9$ & $16.5 \pm 4.9$ & $19.9 \pm 3.8$ & $25.9 \pm 4.4$ & $25.5 \pm 4.0$ & $19.1 \pm 3.4$ & $126.4 \pm 17.7$ \\
\hline
\end{tabular}




\begin{tabular}{|c|c|c|c|c|c|c|c|}
\hline & 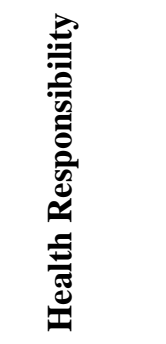 & 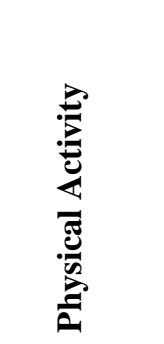 & 总 & 旁 &  &  &  \\
\hline $\mathrm{P}$ value & 0.642 & 0.704 & 0.031 & 0.778 & 0.537 & 0.956 & 0.348 \\
\hline \multicolumn{8}{|c|}{ Education level of father } \\
\hline $\begin{array}{l}\text { Primary } \\
\text { school or } \\
\text { below }\end{array}$ & $18.3 \pm 3.5$ & $15.0 \pm 4.6$ & $18.3 \pm 3.7$ & $25.3 \pm 4.0$ & $24.6 \pm 4.1$ & $18.4 \pm 3.3$ & $120.1 \pm 16.5$ \\
\hline $\begin{array}{l}\text { High } \\
\text { school or } \\
\text { above }\end{array}$ & $19.2 \pm 3.8$ & $16.8 \pm 4.9$ & $19.8 \pm 3.8$ & $26.1 \pm 4.3$ & $25.6 \pm 3.8$ & $19.2 \pm 3.4$ & $126.9 \pm 17.0$ \\
\hline $\mathrm{P}$ value & 0.177 & 0.010 & 0.009 & 0.296 & 0.077 & 0.153 & 0.004 \\
\hline
\end{tabular}

Table 4: Comparison of First-year and Sixth-year Medical Students According to HLBS-II Total and Subscale Scores, (Mean $\pm \mathrm{SD}$ ) Smoking and Alcohol Use

\begin{tabular}{|l|l|l|c|}
\hline \multicolumn{1}{|l|}{} & \multicolumn{1}{|c|}{$\begin{array}{c}\text { First-Year Medical } \\
\text { Student } \\
(\mathbf{n = 1 6 8})\end{array}$} & \multicolumn{1}{|c|}{$\begin{array}{c}\text { Sixth-Year Medical } \\
\text { Student } \\
(\mathbf{n = 1 8 8})\end{array}$} & p Value \\
\hline HLBS-II Total and Subscale Scores (Mean \pm SD) & $19.0 \pm 3.9$ & $19.0 \pm 3.5$ & 0.665 \\
\hline Health Responsibility & $17.4 \pm 4.8$ & $15.6 \pm 4.8$ & $<\mathbf{0 . 0 0 1}$ \\
\hline Physical Activity & $19.8 \pm 4.0$ & $19.3 \pm 3.7$ & 0.346 \\
\hline Nutrition & $26.8 \pm 4.4$ & $25.1 \pm 4.0$ & $<\mathbf{0 . 0 0 1}$ \\
\hline Spiritual Growth & $25.9 \pm 3.7$ & $25.0 \pm 4.0$ & $\mathbf{0 . 0 3 9}$ \\
\hline Interpersonal Relationships & $19.3 \pm 3.5$ & $18.8 \pm 3.2$ & 0.291 \\
\hline Stress Management & $128.5 \pm 17.0$ & $123.1 \pm 16.7$ & $\mathbf{0 . 0 0 3}$ \\
\hline HLBS-II Total & \multicolumn{3}{|l}{} \\
\hline Smoking, and Alcohol Use (\%) & 3.6 & 20.2 & $<\mathbf{0 . 0 0 1}$ \\
\hline Smoking & 15.4 & 25.5 & $\mathbf{0 . 0 1 8}$ \\
\hline Alcohol use &
\end{tabular}




\section{DISCUSSION}

In our study, the average HLBS-II score of the medical students was $125.7 \pm 17.1$ and with regard to this it can be considered that the students exhibit moderate level healthy lifestyle behaviors. The average HLBS-II score ranges between 121-134 in the studies conducted on the healthy lifestyle behaviors of medical students in our country and it is generally similar to the results of our study ${ }^{13-17}$.

In our study, while the total HLBS-II score did not differ significantly by gender, physical activity score was found to be significantly higher in male students. In accordance with our findings, in many studies which were conducted in university students, it was reported that no significant differences were found for total HLBS-II score between genders ${ }^{15,16,18}$. However, Asma et al. and Demir \& Artantaş found that physical activity scores of male students were significantly higher ${ }^{14}$, ${ }^{19}$. These results can be interpreted as male students devote most of their spare time to sports activities and more adopting physical activity as an image of a healthy lifestyle compared to female students.

It was detected that total HLBS-II and nutrition scores were significantly higher for the students who were living with their family than the students who were living in a private house. Similarly, Wei et al. and Ardıç \& Taşkın reported that the nutrition score was found to be significantly higher in students who were living with their families ${ }^{13,} 20$. In Demir \& Artantaş's study in addition to nutrition score, total HLBS-II, health responsibility and interpersonal relationships scores were also reported as significantly higher in the students who were living with their families ${ }^{19}$. Although different results were obtained in some studies on this subject, it is possible to say that living with the family is an important factor in the healthy eating behaviors of the students. It can be thought that students who live alone or with their friends in a home environment will have a higher risk of acquiring fast-food style eating habits for reasons such as saving time and convenience. In our study, the HLBS-II total scores of the students living in the dormitory were found to be significantly higher than the students living in private homes. Contrary to this finding, Ünalan et al. reported that students living in the dormitories generally have lower scores than the other groups ${ }^{21}$. It can be thought that the accommodation conditions and the services provided in the dormitory may play a role in the formation of different results.

In our study, in all subscales scores except of health responsibility and HLBS-II total scores were significantly higher in students with a better perception of health status. Similarly, Ünalan et al. and Nacar et al. observed that healthy lifestyle behavior of the students generally positively improving as their perceived health status level increases 16, 21. These results show that the perceived health level is mostly related to healthy lifestyle behaviors. In addition to this, nutrition score was found to be significantly higher in the students who indicated their economic status as good or very good and this finding was consistent with the study conducted on nursing students by Özyacıoğlu et al. ${ }^{22}$. In many studies, it was observed that a better economic situation is significantly associated with healthy lifestyle behaviors in a positive way ${ }^{15,16,18}$. These results suggest that the economic situation together with social factors play an active role in healthy lifestyle behaviors.

In terms of parents' education level, it was found that total HLBS-II, nutrition and physical activity scores were significantly higher for the students whose fathers' levels of education were high. On the other hand, only nutrition score was found to be significantly higher for the students whose mothers' levels of education were high. Hacihasanoğlu et al. reported in their study that as the education level of the parents increases, total HLBS-II and the majority of the subscale scores increased significantly ${ }^{18}$. Similarly, Nacar et al. reported in their study that the HLBS-II total score of the students whose parents have a high education level was significantly higher ${ }^{16}$. Contrary to these results, in several studies it was reported that the education level of parents was not significantly associated with healthy lifestyle behaviors of the students ${ }^{13,17,23}$. Thus, as well as the education level of the parents, it should be considered that the interaction of the person with the external environment can play a role in the healthy lifestyle behaviors.

In this study, total HLBS-II and the majority of the subscale scores (nutrition, spiritual growth, interpersonal relationships, stress management subscales) were found to be significantly higher for non-smoking students. Bhuiyan et al. reported that non-smoking students had significantly better scores in terms of health responsibility, spiritual growth and total HLBS-II compared to smokers ${ }^{24}$. Furthermore, nutrition score was found to be significantly higher for non-smokers in the study conducted by Ganasegeran at al. ${ }^{25}$. Although there are studies with opposite results, it can be said that smoking mostly is an important indicator for negative lifestyle behaviors ${ }^{21,23}$. 
Similar to non-smokers, total HLBS-II and some subscale scores (nutrition, spiritual growth and stress management subscales) were observed to be higher in the students who were not drinking alcohol. In contrast to our findings, many studies reported that alcohol consumption did not affect healthy lifestyle behaviors significantly $16,19,26$. Considering the personal differences regarding alcohol use, more detailed studies on the amount and frequency of alcohol use will provide a better understanding of the effect of alcohol use on healthy lifestyle behaviors.

Surprisingly, total HLBS-II, physical activity, spiritual growth, and interpersonal relationships scores were observed to be significantly higher among the first-year medical students than the senior medical students. Similarly, in the study conducted by Nacar et al. on medical students, it was determined that the total HLBS-II and the majority of the subscales scores were significantly higher for the first-year students than the senior students ${ }^{16}$.

In various studies conducted in nursing and health schools, it is observed that healthy lifestyle behaviors generally increase as the education years of the students increase ${ }^{27,28}$. It is naturally expected that students who are trained within the scope of health protection and promotion have adopted more healthy lifestyle behaviors as their education years increase. While this expectation is largely met in nursing and other health school students, it cannot be met in medical students and even some negative health behaviors increase as the education year increases. The prevalence of smoking and alcohol use among medical students in our study also supports these results. Similarly, in the study conducted by Majra, it was reported that the percentage of smoking and alcohol use increased significantly during the education process of medical students ${ }^{29}$.

The healthy lifestyle behaviors of the participants were evaluated based on their own statements and this can be considered as a limitation. However, HLBS-II has a high level of validity and reliability and is a frequently used scale in the literature. Therefore, it allowed us to compare our findings with many similar studies.

\section{CONCLUSION}

In this study, it was revealed that the healthy lifestyle behaviors of medical students did not develop at the desired level despite the education they received. In the last year of the education period, medical students work at a high tempo for long hours, attend night shifts and prepare for medical specialty exam, therefore they experience intense stress and future anxiety. The negative health habits that may develop depending on these factors will become permanent in later periods of life and will become an important factor for many chronic diseases. Periodically evaluating the healthy living habits of medical students and implementing multi-sectoral projects that support healthy life on campus within the scope of protecting and improving health should be considered as an important opportunity to increase the health gains of both students and society.

\section{Acknowledgment}

In this study, no funding support was received, and all expenses were provided by the researchers.

\section{REFERENCES}

1.World Health Organization. Healthy living: what is a healthy lifestyle? Copenhagen: WHO Regional Office for Europe, 1999.

2.Pender NJ. Health Promotion in Nursing Practice. Norwalk CT: Appleton-Century-Crofts, 1982.

3.World Health Organization. Fact Sheets. Noncommunicable Diseases. Available from: https://www.who.int/news-room/factsheets/detail/noncommunicable-diseases (Accessed June 10, 2020).

4.Cecchini M, Sassi F, Lauer JA, et al. Tackling of unhealthy diets, physical inactivity, and obesity: health effects and cost-effectiveness. Lancet. 2010; 376(9754): 1775-84.

5.Jimenez EY. World Development Report 2007: Development and the next generation. Washington, D.C: The World Bank, 2006.

6.Abramson S, Stein J, Schaufele M, Frates E, Rogan S. Personal exercise habits and counseling practices of primary care physicians: a national survey. Clin J Sport Med. 2000; 10(1): 40-8.

7.Lewis CE, Clancy C, Leake B, Schwartz JS. The counseling practices of internists. Ann Intern Med. 1991; 114(1): 54-8.

8.Frank E, Rothenberg R, Lewis C, Belodoff BF. Correlates of physicians' prevention-related practices. Findings from the Women Physicians' Health Study. Arch Fam Med. 2000; 9(4): 359-67.

9.Sajwani RA, Shoukat S, Raza R, et al. Knowledge and practice of healthy lifestyle and dietary habits in medical and non-medical students of Karachi, Pakistan. J Pak Med Assoc. 2009; 59(9): 650-5.

10.Walker SN, Hill-Polerecky, DM. Psychometric Evaluation of the Health-Promoting Lifestyle 
Profile II. Unpublished Manuscript, University of Nebraska Medical Center 1996.

11.Walker SN, Sechrist KR, Pender NJ. The Health-Promoting Lifestyle Profile: development and psychometric characteristics. Nurs Res. 1987; 36(2): 76-81.

12.Bahar Z, Beşer A, Gördes N, Ersin F, Kıssal A. Sağlıklı yaşam biçimi davranışları ölçeği II'nin geçerlik ve güvenirlik çalışması. Cumhuriyet Üniversitesi Hemşirelik Yüksekokulu Dergisi. 2008; 12(1): 1-13.

13.Ardıç C, Taşkın N. An Evaluation of Healthy Lifestyle Behaviors of Medical School Students. Bezmialem Science. 2018; 6(3): 191-5.

14.Asma B, Yiğitalp Rençber S, Çetin Dağlı S, Ceylan A. Healthy Life-Style Behaviours And Effecting Factors of Final Year Students Attending to Two Different Medicine Faculties. International Journal of Health Services Research and Policy. 2019; 4(1): 11-21.

15.Kaya G, Save D, Sari A, et al. How does being a medical student determine health promoting behaviors? Marmara Med J. 2018; 31(1): 27-32.

16.Nacar M, Baykan Z, Cetinkaya F, et al. Health promoting lifestyle behaviour in medical students: a multicentre study from Turkey. Asian Pac J Cancer Prev. 2014; 15(20): 8969-74.

17.Şimşek H, Öztoprak D, İkizoğlu E, et al. Tip fakültesi öğrencilerinde sağlıklı yaşam biçimi davranışları ve ilişkili etmenler. DEÜ Tıp Fakültesi Dergisi. 2012; 26(3): 151-7.

18.Hacıhasanoğlu R, Yıldırım A, Karakurt P, Sağlam R. Healthy lifestyle behaviour in university students and influential factors in eastern Turkey. Int J Nurs Pract. 2011; 17(1): 43-51.

19.Demir E, Artantaş AB. Tip ve Hemşirelik Öğrencilerinde Sağlıklı Yaşam Biçimi Davranışlarının Değerlendirilmesi: Kesitsel Bir Çalışma. Ankara Medical Journal. 2018; 18(2): 186-97.

20.Wei CN, Harada K, Ueda K, et al. Assessment of health-promoting lifestyle profile in Japanese university students. Environ Health Prev Med. 2012; 17(3): 222-7.

21.Ünalan D, Şenol V, Öztürk A, Erkorkmaz Ü. Meslek Yüksekokullarının Sağlık ve Sosyal Programlarında Öğrenim Gören Öğrencilerin Sağlıklı Yaşam Biçimi Davranışları ve Öz-Bakım Gücü Düzeyleri Arasındaki İlişkinin İncelenmesi. İnönü Üniversitesi Tıp Fakültesi Dergisi. 2007; 14(2): 101-9.

22.Özyazıcıoğlu N, Kılıç M, Erdem N, Yavuz C, Afacan S. Hemşirelik öğrencilerinin sağlıklı yaşam biçimi davranışlarının belirlenmesi. Uluslararası İnsan Bilimleri Dergisi. 2011; 8(2): 277-332.

23.Karadeniz G, Yanıkkerem Uçum E, Dedeli Ö, Karaağaç Ö. Üniversite Öğrencilerinin Sağllklı Yaşam Biçimi Davranışları. TAF Prev Med Bull. 2008; 7(6): 497-502.

24.Bhuiyan M, Sheng JWK, Ghazali FHB, et al. Health-Promoting Lifestyle Habits among Preclinical Medical Students. Pakistan Journal of Medical and Health Sciences. 2017; 11(2): 490-5.

25.Ganasegeran K, Al-Dubai SAR, Qureshi AM, et al. Social and psychological factors affecting eating habits among university students in a Malaysian medical school: a cross-sectional study. Nutrition Journal. 2012; 11(1): 48.

26.Kurt AS. The Relationship between Healthy Lifestyle Behaviors and Health Locus of Control among Nursing and Midwifery Students. American Journal of Nursing Research. 2015; 3(2): 36-40.

27.Cihangiroğlu Z, Deveci S. Firat Üniversitesi Elazığ Sağlık Yüksekokulu Öğrencilerinin Sağlıklı Yaşam Biçimi Davranışları ve Etkileyen Faktörler. Firat Tip Dergisi. 2011; 16(2): 78-83.

28.Kocaakman M, Aksoy G, Eker H. İstanbul İlindeki Hemşirelik Yüksekokulu Öğrencilerinin Sağlıklı Yaşam Biçimi Davranışları. SDÜ Tıp Fak Derg. 2010; 17(2): 19-24.

29.Majra J. Do our medical colleges inculcate health-promoting lifestyle among medical students: a pilot study from two medical colleges from southern India. Int J Prev Med. 2013; 4(4): 425-9. 